\title{
Evaluating the Criticisms of Fair Trade:
}

\section{How strong is the argument that consumers and businesses should abandon Fair Trade as a means to socialise their economic decisions?}

\author{
Alastair M. Smith ${ }^{1}$
}

\begin{abstract}
This article critically examines some of the most common arguments used to support the view that Fair Trade should be rejected by consumers and businesses seeking to socialise their economic decisions. Overall the paper finds that the majority of such criticisms lack evidential rigor and sophisticated theory and instead rely on a high degree of rhetorical aptitude. While this does not naturally lead to the position that Fair Trade is necessarily beneficial, the conclusion reflects on a substantial amount of positive evidence to suggest that Fair Trade should not be abandoned by consumers or businesses.
\end{abstract}

\section{Criticising Fair Trade: An ironic allegation of injustice?}

As the Corporate Social Responsibility (CSR) agenda expands many businesses are seeking to include Fair Trade goods in their product ranges or more general operational practices. However, despite the this huge expansion of the Fair Trade market there is considerable criticism of the claims made by proponents of these socially and environmentally responsible goods. Writing in Economic Affairs (2008, vol. 28, no. 3), Henderson argues that Fair Trade has not lived up to its name as it has been promoted using misleading and scant evidence, and this position strikes a cord with others who make a similar case (Sidwell 2008).

However, when these arguments are themselves critically evaluated it emerges that having set out such a standard of 'fairness', critics often fail their own litmus test.

\footnotetext{
${ }^{1}$ Alastair M. Smith is a doctoral researcher at the ESRC funded BRASS Centre at Cardiff University. He holds an M.Phil. in Development Studies from the University of Oxford and has spent time working in the field of micro-business development in Central and South America. Alastair M. Smith, The ESRC Centre for Business Relationships, Accountability, Sustainability and Society, Cardiff University, 55 Park Place, Cardiff, CF10 3AT. Smitham3@ cardiff.ac.uk.
} 
Many critiques of Fair Trade are sadly but consistently blighted by the juxtaposition of some well founded points (which make a firm case for engagement and reform) with a raft of others that are poorly substantiated and inappropriately theorised. Persistent issues include an inaccurate understanding of FLO governance; failing to engage with evidence and theory on the benefits of Fair Trade; adopting macro economic analysis based on deductive comparison with perfect market models; and the conflation of the evaluation of the core Fair Trade principles with other fringe issues. Perhaps most markedly is a failure to cite credible empirical evidence to support arguments despite the ironic criticism that proponents of Fair Trade rely on anecdotal and unrepresentative sources (Sidwell 2008, p. 8).

To clarify the stance of this paper: there are certainly aspects of Fair Trade governance that require urgent research and likely reform, and these are addressed throughout the paper and elsewhere (Smith 2008a; Smith 2008b, Forthcoming). Furthermore, I am a firm believer in the liberal principle that the best way to facilitate social progress is through discussion, and therefore that a critical approach is essential in shaping market based solutions to problems of poverty and inequality. However, when rhetoric and argument become separated from appropriate standards of rigor and sophistication, debate ceases to be constructive. If the increasingly pervasive market is to provide solutions to social problems (and if the advocacy of market based solution is to withstand the critique of those who deny this possibility) it is essential that we understand all possible policies in the most detailed and sophisticated manner available. Without such an open minded approach inappropriate options will persist and valuable possibilities dismissed arbitrarily with serious social detriment.

From this overall position I would argue that primary proponents of Fair Trade do have a responsibility to increasingly evaluate the effects of Fair Trade, and while case studies are a valid methodology, more statistically representative evidence is a must. However, this obligation extends equally to those who are critical and the majority of this article highlights the importance of this by deconstructing the current arguments against Fair Trade that are viewed to bring little value to the debate. The conclusion then compares this analysis against existing academic work which finds value in the Fair Trade approach. The overall conclusion of this comparison is that, at this time, 
the available evidence does not support calls for the rejection Fair Trade as a way for consumers and businesses to socialise their economic decisions.

\section{The Rules of FLO Fairtrade ${ }^{2}$}

Given that the broad concept of Fair Trade has been concretised most obviously and perhaps extensively (by volume of trade) in the governance of the Fairtrade Labelling Organizations International (FLO), many critics make reference to these criteria. For example, in discussing how 'firms' qualify for FLO Fairtrade certification, Henderson (2008, p. 62) states that it 'has only little to do with how it treats its employees'. However, assuming that the author followed his own advice to Dan Koeppel and 'actually read the criteria for Fair Trade [ $\left.\mathrm{sic}^{3}\right]$ ' (Henderson 2008, p. 64), he certainly draws a very different conclusion to myself.

While the handful of conditions (about the need for cooperative organisation) mentioned by Henderson do not directly relate to standards of employment, a broader read reveals that the sections covering Labour Conditions in FLO standards are in fact one of the most detailed and considered. The first justification for this suggestion is that far from taking Labour conditions lightly, FLO standards are based on those advocated by the Conventions of the International Labour Organisation (FLO 2009, p. 23). In operationalising this, FLO has embedded around 1,100 words on labour standards (compared to the 600 odd words covering Social Development of which the issue of cooperatives, apparently so strongly emphasised, is but one small section) in its Generic Standards and set detailed requirements in the areas of: employment policy, freedom from discrimination; freedom of labour; freedom of association and collective bargaining; conditions of employment and; occupational health and safety.

In contrast to other established codes of labour, these are largely ${ }^{4}$ not only applicable to full-time workers, but in fact, 'all waged employees of the producer organization

\footnotetext{
${ }^{2}$ While the generic concept is referred to as 'Fair Trade', the singular word 'Fairtrade' refers to the particular interpretation of the Fairtrade Labelling Organizations International (FLO).

${ }^{3}$ By definition FLO regulations represent the specific interpretation of a broader concept, and signifying terms should be differentiated appropriately. See note 2 .

${ }^{4}$ Although, flexibility is given for smaller organisations to which some regulations would not be appropriate.
} 
and of its members....[which] includes migrant, temporary, seasonal, sub-contracted and permanent workers' (FLO 2009, p. 24). Another point well worth noting is that the majority of these requirements are not minimum benchmarks, but are "process requirements' to be met over a three year period. While a negative interpretation might see this is weakness, an alternative view is that such an approach demonstrates how seriously the FLO take the issue of labour rights. Instead of presenting an arbitrary stance discriminating against organisations currently unable to meet 'western' expectations (a problem that has haunted many such efforts in the past), the method seems to me to reflect a genuine effort to use labour codes as a means through which to facilitate genuine improvement.

I would further point out that while cooperatives are promoted due to their democratic structure (which often resonates well with local cultures where Fairtrade has been adopted), the idea of polarising these requirement against a concern for the labour conditions of southern workers is in my opinion somewhat misguided. On this basis then, I propose that arguing FLO standards are little to do with how a firm treats its employees is a very difficult position to substantiate based on analysis of this evidence. What might be a more appropriate issue is how such standards are translated through governance practices into concrete results: an area of future research that I suggest would make a very valuable contribution to the debate about Fairtrade $^{5}$. A further issue might be to what extend these rules for producers organisations are matched by the commitment of buyers and retailers to ensuring that commercial pressures (which are usually seen as the cause of low Labour Standards in the beginning) do not generate a tension with their alleged ethical concerns.

Another argument made with reference to FLO standards is that Fairtrade is alleged to help only 'a select few at the expense of others' (Sidwell 2008, p. 24). As part of this argument it is often asserted that under FLO governance small farmers are unable to take on any hired labour for seasonal tasks and meeting varying demands (Henderson 2008, p. 62; Sidwell 2008, p. 24). This position is in my interpretation categorically incorrect. It is true that the FLO standards that govern Small Farmers' Organisations only apply to those 'not structurally dependent on permanent hired labour' (FLO

\footnotetext{
${ }^{5}$ I am only aware of one such piece of work undertaken by Berlan (2004) and which draws out some of the classic contradictions between western discourses of labour rights and local cultures.
} 
2007b). However, while family farms register for small producer certification (FLO 2007b), any producer group that is structurally dependent on hired labour still has the option to register under alternative certification (FLO 2007a). This does not involve the formation of a cooperative, but instead requires owners to allow workers to unionise or form organisations for the protection of workers rights (FLO 2007a). Furthermore, even those cooperatives certified under the Small Farmers Standard (FLO 2007b) can contract hired labour for seasonal work but more significantly, could be supplied by individual farms reliant on full time hired labour. The exact view of the FLO is that ' $O$ every Fairtrade-certified product sold by the [cooperative] organization, more than $50 \%$ of the volume must be produced by small producers [or those not reliant on paid workers]' (FLO 2007b, p. 5). This obviously means that groups can source up to $49 \%$ of goods from farmers operating with full time paid labour.

More recently the FLO has also revised the definition of a 'small producer' to further ensure that producer realities are accurately-reflected in their Generic Standards. Two definitions are now offered with one being applied to product categories that 1) are not (highly) labour dependent ${ }^{6}$, and 2) are (highly) labour dependent ${ }^{7}$ (FLO 2009, p. 4). In the second category it is now explicitly acknowledged that farmers have the option to hire non-family labour so long as, 'The number of permanent hired workers does not exceed a specific factor per hectare per crop, as defined by the certification body in its compliance criteria' (FLO 2009, p. 4). This means that while governance encourages family based entrepreneurship, it accepts that in some situations, some families may need to make other provisions.

In an extension of the argument that FLO Fairtrade is exclusionary, it is often noted that certification is concentrated in 'relatively developed' countries such as Mexico, and less with lower income countries like Ethiopia (Sidwell 2008, p. 11). While it is pertinent to notice that Fair Trade certification, which first appeared as the Max Havelaar mark, was in fact developed in partnership with Mexican coffee farmers, this macro analysis further misses the point. This is because national income statistics

\footnotetext{
${ }^{6}$ This product category is applicable to the following Fairtrade products: cocoa, coffee, herbs and spices, honey, nuts and oilseeds, quinoa, rice, seed cotton, soybeans and pulses.

${ }_{7}$ This product category is applicable to the following Fairtrade products: bananas, cane sugar, dried fruit, fresh fruit, fresh vegetables, fruit juices, tea, and wine grapes.
} 
entirely obscure the fact that Mexico (for example) is still one of the most unequal societies in the world with a GINI coefficient of $47.9^{8}$. This inequality is manifest in strong income differences in the region of Chiapas, where coffee farmers are some of the poorest individuals in one of the overall poorest regions in Central America (Burbach 1994). Furthermore, the existing ratio of Latin America to African certification is shifting as more African based producer organisations have become involved in Fairtrade Certification (Smith 2008a, p. 23); a reality perhaps aided by the introduction of Contract Standards which help producers with lower capability graduate into the system (FLO 2005b). What is much more pertinent to consider is the inequality of benefit that arises within regions and indeed certain regional and local cooperatives structures (Taylor 2002, p. 25). However, while this issue certainly requires future research and ideally reform it must be considerate that perhaps no development project will ever capture those who are arguably 'most in need' (see below).

\section{The Economics of Fair Trade}

Another misleading aspect of the Fair Trade critique is the view that money spent in goodwill by consumers is lost in the unnecessary administrative cost required to maintain the Fair Trade system. For example, Henderson writes that 'a substantial amount of the gains from the Fairtrade price are eaten up by the co-operative bureaucracy'. While it is not factually incorrect that a portion of the Fairtrade price remains with the cooperative (and indeed that the Fairtrade price is guarantee to the first cooperative level only, and not to individual farmers), I wonder why this must be described as being 'eaten up by bureaucracy', and not perhaps, 'absorbed in administrative and investment costs'? Perhaps such a view stems from a considerable volume of empirical evidence on which Henderson has drawn to discover that large portions of income are being directed away from beneficial usages? In testing this hypothesis we can follow Henderson's citation to his background reading for the debate, but in doing so find that the citation leads to no relevant information on the

\footnotetext{
${ }^{8}$ CIA W orld Fact Book. Mexico. (2006). https://www.cia.gov/library/publications/the-worldfactbook/geos/MX.html [20/07/09].
} 
page indicated ${ }^{9}$. In reading the whole of the cited article it can be noted that while this piece does claim that 'Co-operatives are a notoriously inefficient form of business organisation' (Booth and Whetstone 2007, p. 32), again no evidence is directly cited in support of this statement. Furthermore, this comment is clarified by the original authors, who note that, 'Whether they are efficient or not is beside the point [as]...the corporate forms promoted by the fair trade movement add to, rather than detract from, the institutional variety of a market economy (Booth and Whetstone 2007, p. 29).

From reading the evidence it would certainly be 'unfair' to claim that the cooperative is an ideal system towards which we should all be striving. However, it must be pointed out that where undesirable characteristics have been found in Fair Trade cooperatives, those making direct analysis phrase these as 'costs' vis-à-vis the wider benefits that are found with this organisational type (For example see Milford 2004 as cited by Booth and Whetstone). Another point to add would that one of the primary expenses identified in studies is repaying pre-existing loans which they are now able to pay off thanks to Fairtrade incomes (Taylor 2002, p. 13; Utting-Chamorro 2005, p. 589). This, in my view, means that financial capital used by the cooperative is a positive developmental investment and a far cry from the view that cooperatives are wasting consumers' money. While there is certainly corruption in some cooperatives, again we must consider if this is a product of the institutional form or the nature of the wider economic system? In my view the current reforms in MPs expenses and headlines on pay in the banking sector clearly indicate that it is the latter as opposed to the former.

This efficiency critique also fails to appreciate that costs to run certification systems are not snatched from the hands of needy individuals. The decision to invest in Fairtrade certification and thus carry this cost is take voluntarily by producers, and is thus no different from any other choice made by businesses everyday. Those responsible contribute towards cost-benefit analysis and if no gains are seen, or discovered over time, individuals and indeed whole organisations are free to reject certification as an unhelpful option. In this way, simply quoting the cost of

\footnotetext{
${ }^{9}$ While Henderson refers to page 7, the article in its published format runs from page 29 to 36 . In this way page 7 has been assumed to refer to the $7^{\text {th }}$ page of the article where no relevant supporting evidence can be found.
} 
certification for cooperatives is irrelevant to an evaluation of the system without a consideration of either the returns available to individual cooperatives/farmers, or the way that such licensing fees are subsequently spent by the FLO. Where hard evidence based on such cost-benefit analysis could be cited this is indeed a worthy area for debate.

For example, the degree to which costs place such business options beyond the reach of those most in need is an important issue. On this point it is certainly worth reiterating that in 2005 the FLO introduced a Contract Standard designed to make the certification system more accessible for those with lower levels of financial and business development (FLO 2005a). This certification is accordingly significantly cheaper than standard FLO accreditation (FLO CERT 2007a, 2007b) and perhaps offers a good area for future research aimed at understanding the trade off between 'access to' and 'need for' the certification system. It is certainly likely to remain true that at some level those most in need will not have access to the Fairtrade system due to their lack of capability (Taylor 2002, p. 25). However, this is not a problem confined to the concept of Fairtrade as such barriers to entry arguably exist with every single development intervention available (see the comparison between Fairtrade and micro credit in Smith 2008a). On this basis although such a point of concern should promote continued effort to extend inclusion to the most needy (for Fairtrade and other projects alike) it is in no way naturally extendable to the conclusion that schemes should be scrapped outright.

Another point made in the same vein is that given the amount of money needed to support the certification system, Fairtrade is less efficient than making direct financial transfers to poor communities (Henderson 2008; Sidwell 2008). This point has a large number of problems including the assumption that Fair Trade purchases and charitable giving can be seen as a substitutable acts. Where basic statistical evaluation of this point shows little empirical support for this position (Smith 2008a, p. 18), a simpler approach is to ask if when you choose non-socially certified coffee, do you then donate the difference to charity? While the answer is almost certainly likely to be no, those that continue to view direct aid transfer as a preferable option to internalising the true costs of production (which is essentially what Fair Trade 
attempts by factoring in the cost of basic living and servicing environmental capital) should perhaps consider wider views on this issue.

Indeed, many of the leading experts in the area argue that replacing aid programs with an opportunity to trade under beneficial conditions would be a positive move (Adam and O'Connell 2004). This position is also supported by more philosophical arguments about human dignity (Oxfam 2007), the political economy debates on aid and charity dependence, conditionality and the propensity for volatile and pro-cyclical transfers (Bulíra and Hamann 2007; Hudson and Mosley 2008). While Oxford economist Paul Collier has questioned some of the more extremist rejections of aid as a development tool (1999), he also argues that aid alone has little chance of facilitating sustainable poverty reduction and development (2008, pp. 100-123). Instead, reversing the marginalisation of the poorest communities through trade integration will be essential, and just as Aid for Trade schemes (which transfer financial capital for investment in trade infrastructure) are one element in the solution, the importance of 'learning by doing' has been long established (Arrow 1962). Just as manufacturing firms benefit from practicing tacit production and organisational techniques (Hausmann and Rodrik 2003) - which can then spill over to other local firms - rural communities and agricultural producers need to learn how to integrate effectively with the wider economy . It is for this reason that many producers cite not the additional income but the opportunity to practice increasingly complex business operation within a safe learning environment as one of the key benefits of Fair Trade (Tallontire 2000, p. 170; Taylor 2002, p. 25).

Having said this, perhaps the most powerful critique of Fair Trade is the allegation that where guaranteed minimum prices above the level of the world market are paid, this will inevitably lead to the intensification of current production activities. According to this position where additional output cannot be sold within the Fair Trade system it will be dumped in conventional markets, compounding the problem of oversupply and leading to a further decline in world prices (Henderson 2008, p. 63; LeClair 2002; Sidwell 2008). This argument is even reproduced by Collier who does not see Fair Trade as part of the trade related solution. Instead, he offers a very brief opinion that raising prices 'makes it harder for people to move into other activities' (2008, p. 163) by distorting naturally occurring price incentives. However, while there 
is certainly evidence that government backed subsidies foster increased production, as Henderson $(2008$, p. 63) points out, this evidence is unrelated to Fairtrade as while governments honour fixed prices irrespective of demand, Fair Trade still works within market mechanisms (Barratt Brown 1993). Thus, in my view, to assume that poor producers will increase supply based on unit price and in isolation from a consideration of the level of demand (information about which the FLO makes express efforts to communicate through business development representatives) is a somewhat patronising account of farmers in the developing world. This is especially true as despite a lack of opportunities, we are discussing some of the most effective entrepreneurs in the world; not because they make millions, but because they manage incredible levels of risk and still continue to feed their families despite overwhelming structural constraints.

Indeed, where we consider the empirical evidence (of which none is ever cited by those making this criticism), I know of no research that support this suggestion (which is of course different from saying that this does not happen). On the other hand there are numerous documented examples in which Fair Trade producers have engaged in diversification, and thus to some degree, have offset the problems of over-production and over reliance (Bacon 2005; Doherty and Tranchell 2005, p. 170; Milford 2004, p. 54; Raynolds 2002, p. 17; Ronchi 2003; Taylor 2002, p. 14; Utting-Chamorro $2005)^{10}$. Furthermore, while this issue is exceptionally complex, and as such is addressed at length elsewhere (Smith Forthcoming), it can be noted here that there is a large amount of microeconomic literature that questions the validity of the above largely macroeconomic critique (Also see Smith 2008a part 4). This wider empirical evidence shows conclusively that market incentives are not adequate to facilitate diversification by poor producers. This is because the very condition of poverty means that such decisions are almost universally retarded by: 1) the risk associated with adopting new if not more financially attractive income strategies and 2) and the absolute lack of capabilities necessary to operationalise such strategies. It is for these reason poor producers continuously forgo profitable diversification for less risky (and

\footnotetext{
${ }^{10}$ For a summary see Smith (Forthcoming). What remains unclear however, is to what extent such diversification contributes to household income - another subject that is of great importance for future research.
} 
thus less profitable) activities, despite the existence of market incentives that push them away from current livelihoods.

With the idea that diversification can be facilitated by simply 'getting the prices right' under serious question, there is room to evaluate Fair Trade not against perfect market models, but the real world options that exist where such support is not available. In working towards this project microeconomic evidence provides support for the hypothesis that by providing more stability and alleviating capacity constraints, Fair Trade provides a targeted response to real world problems that deductive evaluation from economic theory grossly ignore (Smith 2008a Part Four; Smith Forthcoming). A further aspect of reality missed by critics is that because Fair Trade operates in economies with labour surpluses it is mostly likely to keep people from unemployment, not more efficient activities in other sectors (Hayes 2008).

\section{The Fair Trade Flight from Quality}

Critics of Fair Trade usually argue that as producers will naturally sell the best quality products to open markets, they will dump poor quality goods on Fair Trade cooperatives which are assumed to have no quality controls (Henderson 2008, p. 63; Sidwell 2008, p. 14). Again, this view is often a product of theoretical deduction and bereft of empirical evidence and is again in my view rather misleading for those making decisions about the value of Fair Trade.

When we compare this position to the available evidence, firstly we find that the presumption that FLO governance has no quality controls is incorrect: while many Product Standards state quality requirements ${ }^{11}$, Generic Standards require certified organisation to make yearly plans for business development which should specifically include, 'creating and maintaining good quality' (FLO 2006, p. 5). Secondly, in order for this assumption to stand, we must further assume those buying and processing Fair Trade products higher in the value chain will not have quality standards either. This however seems very unlikely given the ability of buyers to pick and choose among

\footnotetext{
${ }^{11}$ For an illustrative example see Appendix 1 from the FLO product standards for Bananas produced by small farmers' organis ations.
} 
Fair Trade certified cooperatives (Smith 2007). As a hypothetical example, why would Smith's Coffee Roasters Inc. accept poor quality Fair Trade beans when they could get better quality Fair Trade at the same price from a different cooperative? The empirical reality is that cooperatives must still compete among themselves (Taylor 2002, p. 25) and as the prominent Cambridge economist Mark Hayes (2006) notes, this will breakdown oligopolistic market structures and reinforce competition - a move that will arguably promote both efficiency and improved quality in the future ${ }^{12}$.

Thirdly, while there might be some evidence that farmers sell better quality output in conventionally governed markets ${ }^{13}$, this needs to be qualified and triangulated with other evidence before it can be claimed as an accurate and 'fair' representation. On this point it has been noted that while pressure for improved quality might take time to emerge, cooperatives do punish inferior contributions (Bacon 2005, p. 505), as well as offering incentives for farmers for increase standards. Indeed, evidence from Tanzania shows that cooperatives have responded to wider incentives by paying price premiums to farmers for Special Grade coffee within the FLO Fairtrade framework (Parrish et al. 2005, p. 182). Furthermore, increased income and Social Premiums have helped other cooperatives to invest in quality control. For example, the building of cupping facilities has in some cases allowed producers to actually try their end product for the very first time (Raynolds 2002, p. 17; Utting-Chamorro 2005).

In the light of this evidence the assumption that Fair Trade governance reduces quality can be seriously questioned. As for Henderson's (2008, p. 63) comparison between cooperative organisation and the tragedy of the commons: it can be noted that even Hardin (1968), who most famously reproduced the $19^{\text {th }}$ century assertion that a lack of ownership would lead to degradation, admitted that his article should have been called "The Tragedy of the Unmanaged Commons" (The Economist 2008). The reason for this is well summarised by the World Bank economist Robert Wade (1987), who concludes after a wide spread review that,

'There can thus be no general presumption that collective action will fail in the management of common property resources, any more than there can be a general

\footnotetext{
${ }^{12}$ Also see Milford (2004) and Booth and Whetstone (2007).

${ }^{13}$ I have not reviewed the report by C. E. H. Berndt Does Fair Trade Coffee Help the Poor, as I have not been able to obtain a copy.
} 
presumption that it will work... The chances of success through collective action depend on the characteristics of the resources, the user group, and group-state relations'.

In this light just as there should be no assumption that the common management of land will not inevitably lead to resource degradation, no such assertion can be accepted on the link between common manageme nt and poor quality production.

On a forth point, it is often suggested that somehow Fair Trade consumers are misled in to thinking they are getting better quality or contributing in a way that they are not. However, it is increasingly realised that while economic analysis has classically worked only with physical qualities in evaluating utility vectors (proxied by consumer satisfaction), products and consumer preferences are also composed of socially constructed quality elements (Zeithaml 1988). While concentration on physical quality produces the normative concentration in this area, it ignores the social conditions that promote human welfare: a view largely responsible for the existence of many of the unsustainable features of the world today. When analysis of value and quality are more sophisticated (Raynolds 2000, p. 306; Zeithaml 1988) it can be argued that Fair Trade consumers are always getting improved quality given the additional utility derived from social qualities. Instead of externalising everything beyond physical characteristics, a fuller conception of value takes into account the welfare of all stakeholders associated with the product, as well as the "external preferences' of the consumer (Golding and Peattie 2005; Mann 2008). This approach accepts that even if utility from physical satisfaction 'might' (but not necessarily) be less, fulfilment from making a social and environmental contribution cannot be forgotten in analysing how preferences are being met.

Another point here is that it is often quoted with surprise that the whole difference in price between Fair Trade and non Fair Trade goods does not reach the producer. However, this has never been a claim of the contemporary mainstream Fair Trade system (particularly the FLO which has never claimed that its certification shortens the value chains either) nor is this phenomena specific to the sector. To pick on a specific example, Sidwell (2008, p. 11) generalises that 'just $10 \%$ of the premium paid for Fairtrade coffee reaches the producer'. However, as I have pointed out elsewhere (Smith 2008a), little of Sidwell's report stands up to critical analysis. In 
this example, not only is a single case turned into a generalisation, but if we trace the citation to the original analysis it is discovered that the original author makes it clear that this figure is inflated not by the curiosities of Fair Trade, but by the profit driven retailer (Harford 2006, p. 33). While such price inflation has been a characteristic of Fair Trade in the recent past, as markets have matured prices have fallen under competition and thus the legitimacy of this complaint has declined even more over time. As is clear from a visit to the supermarket, Fair Trade goods are in some cases cheaper than their conventional equivalents due to the nature of corporate marketing and pricing strategies.

\section{The Question of Technology}

Another problem that has been raised with FLO Fairtrade governance is that it refuses producers the option to use genetically modified organisms (GMOs). This argument is specifically constructed by Henderson (2008, pp. 63-64) who says that as a result, the FLO threaten the existence of bananas and the livelihoods connected with their production. While it is true that FLO regulation prevent the use of GMOs, or more accurately transgenic technologies ${ }^{14}$, I do question the way that evidence is used to reach such dramatic conclusions about Fair Trade. My first reason is that these issues are exceptionally complex. While such technology has great theoretical potential, and might indeed be the 'best hope' for growing a hardy banana (Koeppel p. xviii cited in Henderson 2008, p. 63), it is certainly no silver bullet for development and food security problems. While the concrete possibilities are far behind the theoretic potential there is considerable trepidation about unanticipated and unpredictable consequences - the possibilities for which are already empirically observed (Dona and Arvanitoyannis 2009). Perhaps the most relevant problem is the political nature of this technology. Given the issues of ownership and the way such techniques are researched, developed and commercialised, many scholars see them as perpetuating a system of power that inherently tends towards reinforcing poverty and inequality (Patel 2007; Roberts 2008, pp. 239-268) - and as a consequence galvanising the very social problems that Fair Trade was specifically developed to resist. The point here is

\footnotetext{
${ }^{14}$ Those working in the field tend to prefer the concept of transgenic technologies as all organisms are in a sense 'genetically modified' during the natural reproductive processes.
} 
not to deny the potential that science has to contribute to development, but to question the position that such technology offers to circumvent what are essentially politically constructed problems (Sen 1981).

Indeed, the case of the banana is particularly complex and might indeed require an open mindedness to Transgenic technology under the right technological, social and political conditions. As Koeppel (2007) points out, bananas are among the most threatened and disease-vulnerable crops in the world. They are also, by nature of their biology, among the most difficult to conventionally breed. As a consequence, developing a resistant banana by conventional breeding, even if possible, can (and does) take decades. Genetic engineering might cut that time by half, or even more. While this potential has commercial export value, perhaps a more important point is the benefit that these measures could make to populations that depend on bananas for most of their calories - across much of tropical Africa for example ${ }^{15}$. For these reasons, transgenic technology might prove a significant benefit for bananas production, especially given that once bananas have been grown, the prospects for diversification are very limited given the effect that such crops have on the soil ${ }^{16}$.

For this reason, there might be ground to argue that the FLO should critically reevaluate its current policy, but only where revision is based on comprehensive knowledge and thorough analysis (and this is a viewed shared by the European Union in maintaining a precautionary approach to such technology). This would need to take into account not only the physical benefits from transgenic techniques, but also ensure that the legal and political nature of access to such technologies did not mitigate gain in financial, social or environmental cost to the developing world.

\section{Conclusion: Can we reject the hypothesis that Fair Trade contributes to poverty reduction and development?}

\footnotetext{
${ }^{15}$ I am indebted to Dan Koeppel for taking the time to discuss these issues with me as I was preparing this paper.

${ }^{16}$ I thank Dr. Pam Robinson for highlighting this aspect of banana ecology during a recent meeting.
} 
While the issue of ransgenic material must be seen as complex, is it nevertheless 'fair' to reflect on the wider issues and evidence and conclude that consumers and business should abandon Fair Trade as a way of socialising their economic decisions? Should Fair Trade be rejected as part of the CSR agenda? As will already be plain from my commentary I believe that such a conclusion cannot be justified at the present time. When the majority of commentary on Fair Trade is critically analysed it becomes apparent that there is more rhetoric than substance; a particularly ironic outcome given that one of the major criticisms of Fair Trade is that it has risen to notoriety despite a lack of supporting evidence. While there is a considerable volume of evidence and discussion available to analyse the value of Fair Trade governance (below), critics drawn on little of it in reaching their conclusions. Indeed, those who make reference to the inadequacies of FLO governance are often mistaken in their interpretations and the argument on the efficiency of Fair Trade is assumed rather than substantiated. Critics usually assert that Fair Trade is bound to result in low quality standards but this fits little with either analysis of governance frameworks or the triangulation of empirical experience. Furthermore, the view that Fair Trade will retard diversification is grounded not in empirical analysis but in the comparison with perfect market models; an approach that a long standing tradition of empirical research paints as an inappropriate means of analysing the diversification decisions of poor agricultural producers due to the unrealistic assumptions this entails.

Another point is the rather unhelpful binary constructed by critics, and largely reinforced by supporters, in which consumers and businesses are presented with a choice between Fair Trade governance and free trade organisation (as achieved by liberalisation). While Fair Trade works within market mechanisms (as can been seen in the differentiated price structures operating inside cooperatives and the price competition now applied to those retailing Fair Trade), much of the conventional trade in commodity agriculture is structured by monopoly or oligopolistic relations which reflect in no way the assumption of free market models (Barratt Brown 1993). For these reasons it is not a black and white choice between Fair Trade and free trade, 
especially when it is considered that the majority of, if not all cases of successful trade liberalisation have emerged out of the careful management of market forces ${ }^{17}$.

Indeed the nuances of theoretical and empirical literature make plane the necessity to guide the operation of market mechanisms to work for those who are otherwise unable to compete due to absolute poverty in terms of their capability bundle (Greenwald and Stiglitz 2006; Rodrik 2007; Wade 1990). While liberalisation is likely to be an essential part of the development process there is significant evidence that appropriate management in prior stages must build capacity for less developed economies to benefit from greater economic integration (Chang 2002; Smith 2008a, pp. 42-44) ${ }^{18}$. It is for this reason that what is need for pro-poverty reducing development is appropriate governance that facilitates the beneficial integration of poorer regions into the globalising economy by building their capacity to compete successfully (Smith 2008a).

On this note, we can contrast the largely unsubstantiated critiques of Fair Trade with that evidence which supports the use of the system as a way to build capacity that would otherwise not exist ${ }^{19}$. For example, independent empirical research shows that Fair Trade often increases individual family incomes (Bacon 2005; Becchetti and Costantino 2008), and makes credit available to communities that otherwise experience market failure for this vital service (Doherty and Tranchell 2005, pp. 173174; Milford 2004, p. 53). Furthermore, such politically structured governance brings non-financial benefits which would not come from simple financial transfers (see above). Amongst the demonstrated improvements in nutrition, health and education (Bacon 2005; Taylor 2002; Utting-Chamorro 2005), Fair Trade is seen by producers and analysis as being beneficial in increasing economic stability and strengthening markets by breaking down oligopolistic structures (Hayes 2006; Milford 2004). One of the most valuable inputs from Fair Trade is that it builds economic capacity as producers 'learn by doing' in a context that protects human lives against poverty and unacceptable hardship (Smith 2008a, pp. 46-67; Tallontire 2000; Taylor 2002).

\footnotetext{
${ }^{17}$ As an extension it is now recognised, more than ever, that political regulation of financial markets might always remain an import part of maintaining economic stability (Wade 1998).

18 The argument that liberalisation is not enough has even been acknowledged by some of its most vocal advocates (Donaldson 2008).

${ }^{19}$ For a more extensive summary of the beneficial impact of Fair Trade see Le Mare (2008) and Smith (2008a).
} 
It is obviously important to stress that not all evidence is so supportive of Fair Trade (Moberg 2005; Sick 2008) and there might be a bias in the current literature which favours research of more successful examples over less impressive cases (Smith 2007). For this reason further research and analysis is clearly essential to ensure that resources are not being allocated ineffectively and the majority of this responsibility must be taken up by those at the fore of the Fair Trade system ${ }^{20}$. However, while positive evidence is based on case study work and counter examples do exist, the current weight of evidence is far from sufficient to support the call to "quit buying fair trade' (Henderson 2008, p. 64).

While it has not been my intention to offer an argument explicitly in favour of Fair Trade, I hope that I have illustrated than many of the popular arguments against it are far from well founded. I would encourage consumers and businesses to contrast this with an emerging and empirically grounded consensus on the positives of Fair Trade (Becchetti and Costantino 2008); many of which are accepted by the critics themselves (Sidwell 2008). Overall I would urge those interested in these debates continue to support Fair Trade while at the same time remaining reflective and critical in their approach - viewing the system as an excellent start in need of reform, and certainly no perfect or finished solution to all the world's problems. Finally, I would like to comment that while provoking debate is imperative, this is only 'fairly', and in my opinion 'responsibly' extended to policy recommendations when arguments are grounded in empirical evidence and sophisticated theory. We must recognise that for those without the means (time, motivation or skills) to make critical assessments, discursive constructs very quickly become established as 'truth' - which at best bring benefit only through serendipity. For this reason I strongly recommended that the principles of 'evidence based policy' remain paramount in the minds of both critics and advocates alike.

\footnotetext{
${ }^{20}$ Specifically, I suggest that FLO (who sets standards) and FLO-CERT GmbH (who audit producers) collaborate to integrate a significantly intensified program of research as part of their auditing operations.
} 


\section{$\underline{\text { References }}$}

Adam, C. S. and O'Connell, S. A. 2004. Aid versus Trade Revisited: Donor and Recipient Policies in the Presence of Learning-by-Doing. The Economic Journal 114(492), pp. 150-173.

Arrow, K. J. 1962. The Economic Implications of Learning by Doing. The Review of Economic Studies 29(3), pp. 155-173.

Bacon, C. 2005. Confronting the Coffee Crisis: Can Fair Trade, Organic, and Specialty Coffees Reduce Small-Scale Farmer Vulnerability in Northern Nicaragua? World Development 33(3), pp. 497-511.

Barratt Brown, M. 1993. Fair Trade: Reform and Realities in the International Trading System. London: Zed Books.

Becchetti, L. and Costantino, M. 2008. The Effects of Fair Trade on Affiliated Producers: An Impact Analysis on Kenyan Farmers. World Development 36(5), pp. 823-842.

Berlan, A., C. 2004. Child labour, education and child rights among cocoa producers in Ghana. In: Anker, C.v.d. ed. The Political Economy of Slavery. New York: Palgrave, pp. 158-178.

Booth, P. and Whetstone, L. 2007. Half a Cheer for Fair Trade. Economic Affairs 27(2), pp. 29-36.

Bulíra, A. and Hamann, A. J. 2007. Volatility of Development Aid: From the Frying Pan into the Fire? World Development 36(10), pp. 2048-2066

Burbach, R. 1994. Roots of the Postmodern Rebellion in Chiapas. New Left Review 205.

Chang, H.-J. 2002. Kicking Away the Ladder - Development Strategy in Historical Perspective. London: Anthem Press.

Collier, P. 1999. Aid 'Dependency': a Critique. Jounral of African Economies 8(4), pp. $528-545$

Collier, P. 2008. The Bottom Billion : why the poorest countries are failing and what can be done about it. Oxford: Oxford University Press.

Doherty, B. and Tranchell, S. 2005. New Thinking in International Trade? A Case Study of The Day Chocolate Company. Sustainable Development 13, pp. 166-176.

Dona, A. and Arvanitoyannis, I. S. 2009. Health risks of genetically modified foods. Critical Reviews in Food Science and Nutrition 49(2), pp. 164-175. 
Donaldson, J. A. 2008. Growth is Good for Whom, When, How? Economic Growth and Poverty Reduction in Exceptional Cases. World Development 36(11), pp. 21272143.

FLO 2005a. Fairtrade Standards for Contract Production Projects. FLO.

FLO 2005b. Fairtrade Standards for for Contract Production Projects.

FLO 2006. Explanatory Document for the Generic Fairtrade Standard For Small Farmers' Organisations.

FLO 2007a. Generic Fairtrade Standards for Hired Labour. FLO.

FLO 2007b. Generic Fairtrade Standards for Small Farmers' Organisations.

FLO 2009. Generic Fairtrade Standards for Small Producers' Organizations. FLO.

FLO CERT 2007a. FLO-CERT Producer Certification Fees: Contract Production Projects. FLO CERT.

FLO CERT 2007b. FLO-CERT Producer Certification Fees: First grade Small Farmer Producer Organization. FLO CERT.

Golding, K. and Peattie, K. 2005. In search of a golden blend: perspectives on the marketing of fair trade coffee. Sustainable Development 13(3), pp. 154-165.

Greenwald, B. and Stiglitz, J. 2006. Helping Infant Economies Grow: Foundations of Trade Policies for Developing Countries. American Economic Review 96(2), pp. 141146.

Hardin, G. 1968. The Tragedy of the Commons. Science 162, pp. 1243-1248.

Harford, T. 2006. The undercover economist : exposing why the rich are rich, the poor are poor--and why you can never buy a decent used car! New York: Oxford University Press.

Hausmann, R. and Rodrik, D. 2003. Economic Development as Self-Discovery. Journal of Development Economics 72.

Hayes, M. 2006. On the efficiency of fair trade. Review of Social Economy 64(4), pp. $447-468$.

Hayes, M. G. 2008. "Fighting the Tide: Alternative Trade Organizations in the Era of Global Free Trade"- A Comment. World Development 36(12), pp. 2953-2961.

Henderson, D. 2008. Fair Trade is Counterproductive and Unfair. Economic Affairs 28(3), pp. 62-64.

Hudson, J. and Mosley, P. 2008. Aid Volatility, Policy and Development. World Development 36(10), pp. 2082-2102. 
Koeppel, D. 2007. Banana: The Fate of the Fruit That Changed the World. New York: Hudson Street Press.

Le Mare, A. 2008. The impact of fair trade on social and economic development: A review of the literature. Geography Compass 2(6), pp. 1922-1942.

LeClair, M. S. 2002. Fighting the Tide: Alternative Trade Organizations in the Era of Global Free Trade. World Development 30(6), pp. 949-958.

Mann, S. 2008. Analysing fair trade in economic terms. Journal of Socio-Economics 37(5), pp. 2034-2042.

Milford, A. 2004. Coffee, Co-operatives and Competition: The Impact of Fair Trade. Postterminalen, Norway: Chr. Michelsen Institute Development Studies and Human Rights.

Moberg, M. 2005. Fair Trade and Eastern Caribbean Banana Farmers: Rhetoric and Reality in the Anti-Globalization Movement. Human Organization 64(1), pp. 4 - 15.

Oxfam 2007. Regaining dignity through cash-for-work.

Parrish, B. D., Luzadis, V. A. and Bentley, W. R. 2005. What Tanzania's coffee farmers can teach the world: A performance-based look at the fair trade-free trade debate. Sustainable Development 13(3), pp. 177-189.

Patel, R. 2007. Stuffed and Starved: Markets, Power and the Hidden Battle for the World Food System London Portobello Books Ltd

Raynolds, L. T. 2000. Re-Embedding Global Agriculture: The International Organic and Fair Trade Movements. Journal of Agriculture and Human Values 17, pp. 297309.

Raynolds, L. T. 2002. Poverty Alleviation Through Participation in Fair Trade Coffee Networks: Existing Research and Critical Issues. Colorado: Colorado State University.

Roberts, P. 2008. The End of Food. London: Bloomsbury.

Rodrik, D. 2007. One Economics, Many Recipes: Globalization, Institutions, and Economic Growth. Oxford: Oxford University Press.

Ronchi, L. 2003. Fair Trade Impact Monitoring and Evaluation Progress Report. Brighton: University of Sussex.

Sen, A. 1981. Poverty and famines. In: An essay on entitlement and deprivation. Oxford Oxford University Press.

Sick, D. 2008. Coffee, farming families, and fair trade in Costa Rica: New markets, same old problems? Latin American Research Review 43(3), pp. 193-208. 
Sidwell, M. 2008. Unfair Trade. London: Adam Smith Institute.

Smith, A. M. 2008a. "The Fair Trade Cup is 'Two-Thirds Full' not 'Two-Thirds Empty'” Cardiff: ESRC Research Centre: Business Relationships, Accountability, Sustainability and Society. Cardiff University.

Smith, A. M. 2008b. Fair Trade in the 'Periphery': The development of Comercio Justo México and potential lessons for FLO Fairtrade. Cardiff: ESRC Centre for Business Relationships, Accountability, Sustainability and Society. University of Cardiff.

Smith, A. M. Forthcoming. Fair Trade, Diversification and Structural Change: Towards a broader theoretical framework of analysis. Oxford Development Studies.

Smith, J. 2007. The Search for Sustainable Markets: The Promise and Failures of Fair Trade. Culture and Agriculture 29(2), pp. 89-99.

Tallontire, A. 2000. Partnerships in fair trade: reflections from a case study of Cafe 'direct. Development in Practice 10, pp. 166-177.

Taylor, P. 2002. Poverty Alleviation Through Participation in Fair Trade Coffee Networks: Synthesis of Case Study Research Questions and Findings.

The Economist 2008. Why it still pays to study medieval English landholding and Sahelian nomadism.

Utting-Chamorro, K. 2005. Does fair trade make a difference? The case of small coffee producers in Nicaragua. Development in Practice 15(3), pp. 584 - 599.

Wade, R. 1987. The Management of Common Property Resouces: Finding a Cooperative Solution. World Bank Res Obs 2(2), pp. 219-234.

Wade, R. 1990. Governing the Market: Economic Theory and the Role of Government in East Asian Industrialization. Princeton: Princeton University Press.

Wade, R. 1998. The Asian debt-and-development crisis of 1997-?: Causes and consequences. World Development 26(8), pp. 1535-1553.

Zeithaml, V. A. 1988. Consumer Perceptions of Price, Quality, and Value: A MeansEnd Model and Synthesis of Evidence. Journal of Marketing 52(3), pp. 2-22. 